\title{
The Pain and Turmoil as Inevitable Result of Emotional and Physical Displacement in Hosseni's the Kite Runner
}

\author{
Dinesh Lohani $^{{ }^{*}}$, Suresh Lohani ${ }^{2}$ \\ ${ }^{I}$ Master's degree in sociology from Tribhuvan University \\ ${ }^{2}$ Two master's degrees in English from Pokhara University
}

*Corresponding Author: Dinesh Lohani, Master's degree in sociology from Tribhuvan University

\begin{abstract}
Khaled Hosseini's The Kite Runner is a good example of how trauma results out of displacement that happens both emotionally and physically. Having to forcibly leave one's comfort zone for whatever reason inflicts pain that may not overtly manifest in the characters' actions as they engage in day to day lives. However, the scar it leaves in their hearts is there to stay and profoundly affects their emotional stability and geographical positionality. Having showcased the divide within different derivatives of Islam, Sunnis and Hazaras, the novelist explicitly demonstrates how divisions on grounds of race and socio-economic status tamper with manifold dimensions of people's lives and lead to misery and discontentment regardless of all the physical gains they may achieve with the due course of time. This paper will talk about some of the lead characters in the novel such as Amir, Baba and Hassan to show how they wrestle with various challenges of life as a result of physical, emotional and psychological displacement, and how that wreaks havoc in their lives in different ways.
\end{abstract}

Keywords: Displacement, Turmoil, Pain, Trauma

Khaled Hosenni's digging into the elements of pain and turmoil are based on the issue of layered displacement that occurs at various episodes at the time of Russian invasion of Afghanistan and in its aftermath. The paper will not follow the chronology of the events that unfold in the novel, but rather will be invested in showing how displacement at different intervals of time, and at different locations, affect the everyday of the characters in The Kite Runner. As Baba and Amir are thrown to the American setting after battling with excruciating circumstances in Afghanistan, it can be deduced that despite the "comfort" and solace which America provided, Amir, Baba and the general among others still lived in "exile."There remained some inarticulate longing alternating with manifested voice in their heart for their roots. Thus once displaced from the comfort zone, trauma whether subtle or visibly acute, keeps haunting the migrants. And these torrid emotional remnants often compel the migrants to retreat to the country of their origin as the memories keep them tied to familiar settings of the native land as Baba in the U.S. "missed the sugarcane fields of Jalalabad and the garden of Paghman. He missed people milling in and out of his house, missed walking down the bustling aisles of Shor Bazaar and greeting people who shared ancestors with him, whose pasts intertwine with his" ( Hosseini, p. 70). The "comfort zone elements" of the home country continue to pain and lure Baba to Afghanistan. The images of different locations and reminisces of different activities in which Baba was indulged in Afghanistan in the past flash across his mind leaving a profound imprint on him.

However, even the general is not spared with the recollections of Afghanistan. He is enveloped with wishful thinking which he feels shall materialize one day and that it was only the matter of time. The general believed that, sooner or later, Afghanistan would be freed, the monarchy restored, and his services would once again be called upon. So, every day, he donned his gray suit, would his pocket watch, and waited with a faint hope for returning (Hosseini 96). These two characters also perhaps point to an idea that those hard hit by displacement are probably the eminent personalities from different walks of life who distinctly stand out in the crowd. Both the general and Baba were notable figures who enjoyed a high degree of influence and repute back in Afghanistan, and in America they live like any other ordinary, struggling migrant. That must have caused them extra agony which comes to be displayed through the musings of their heart. This is one other exposition of trauma on the part of these influential figures of Afghanistan of yesteryears for "One of the striking 
characteristics of trauma is the salient visual aspects of its "episodic memory, which, unlike the general "semantic" memory, is highly emotionally charged and stays in an activated, "primed" state without being integrated with other memories" (Hwangbo, p. 3). Thus, the flashbacks of the past keep haunting the displaced characters in different ways, adding fuel to the fire of displacement.

The above discussed notion of "episodic memory" when placed alongside Amir and dealt with, however, evokes a totally different response from him. Amir who left Afghanistan at a young age of twelve did not, perhaps, retain the memories of his native land much longer. One could argue that there are many reasons, particularly the ones connected with Hassan, which may have made Amir oblivious to the change in location or conversely, even functioned as an emancipatory experience.

However, the other interpretation could also be that the when Amir left Afghanistan he was not old enough to feel the intensity of attachment associated with one's land or that he had not really had the opportunities to acquaint himself with various social and geographical entities of Afghanistan; whatever memories he had of the native land were basically connected with jealousy, and pain. And expressing along the very line Amir feels that America helped him relieve his emotional burdens. Further, to Amir, "America was different. America was a river, roaring along, unmindful of the past. I could wade into this river, let my sin drown to the bottom, let the waters carry me someplace far. Some place with no ghost, no memories and no sins" (Hosseini, p. 119). In a way it is a kind of a paradoxical explanation that displacement may not always embody with it tragic elements. Particularly for those who, perhaps, do not have to bear the pangs of pain of parting, and do not have to shoulder the burden of supporting themselves in a foreign location, displacement may not really sting painfully.

Alternatively, for the ones who are ailed for some reason in their own familiar locations or the ones harboring certain feelings of guilt or discomfort, displacement in fact could be more a renunciation and may come as a blessing in disguise. Amir, for example, was laden with the burden of the past and that if he were in the settings of Afghanistan itself- it may no doubt sound quite hypothetical - the piercings of his unjust and highly immoral act on Hassan would most probably torment him to the point of madness. The on and off exposure to the sites of their activities would quite likely remind him of the ill treatment that he inflicted on Hassan and he would be pregnant with remorse of his unethical act. However, the entirely different landscape of America helped him overcome the regret of having committed such a heinous act on such a loyal and unwaveringly supportive friend.Amir says "For me, America was a place to bury my memories. For Baba, a place to mourn his" ( Hosseini, p. 112). The locations of refuge in the aftermath of displacement thus evoke varied emotions on different characters, and it is largely contingent upon personal profiles and statures of the characters.

However, reading between the lines it would not be difficult to infer that even when Amir talks about "place to bury my memories" he is constantly haunted by his wrongdoing and the undertone where binary opposites of the above quoted phrase pervade the literal interpretation; perhaps it is that since he is so far away from the native land, there is no way in which he can now rectify his mistakes. So it is a case of ambivalence: displacement has to an extent offered respite to Amir from the burden of his wretched history, but then almost imperceptibly reminds Amir of how he is with every passing minute trying to wash himself of the sin that simply would not be divorced from him. Next, the overwhelming attachment which Amir always nurtures in his heart for Afghanistan is alternately reflected when he makes utterances connected to Afghanistan and his familiar locations of the past years as while travelling with Farid he utters, "I feel like a tourist in my own country" (Hosseini, p. 203). It is worth mentioning Ashok Bhusal's (2019) article titled "The rhetoric of racism in society" in which he says that "racist attitudes and behaviors cause problems for the marginalized communities" (p.114).

It is yet another instance of no matter how hard one tries to erase the connection one has with his history or roots, the resurgence of memories is bound to occur and hit back psychologically, unearthing the hard concealed psychological trauma.

Trauma often wreaks havoc with regularities and belief systems of the affected individuals. Kolk in The separation Cry and the Trauma Response states that "The essence of psychological trauma is the loss of faith that there is order and continuity in life. Trauma occurs when one loses the sense of having a safe place to retreat within or outside to deal with frightening emotions of experiences" (qtd. 
in Alexander, p. 20). This can be understood against the backdrop of Assef's displacement as well, for he shares resentfully with Amir that "Afghanistan is like a beautiful mansion littered with garbage, and someone has to take out the garbage" and further says to Amir scornfully that "there are things traitors like you don't understand" ( Hosseini, p. 155). Assef perceived a great sense of identity crisis since the invasion of the Russians and according to Louis Kriesberg in Identity Issues "Although selfidentity may seem to coincide with a particular human being, identities are actually much wider than that. They are also collective identities extended to countries and ethnic communities, so that people feel injured when other persons sharing their identity are injured or killed" (Kriesberg, p. 1). The treatment of the Russians towards Afghanis seemed to have deeply tormented Assef and to "protect" the perceived identity of his people; he resorts to uniting people to ensure a collective resistance against the Russians.

With the arrivals of the Russians the inner socio-cultural fabric of Afghanistan saw an unprecedented change and those who enjoyed power in the past found themselves either escaping the scenario like Baba and Amir or aggressively trying to defend their prominence like Assef and the like, and new power equations came into the scene. For example, those Pashtuns like Assef were retained within Afghanistan itself during the Russian invasion and even joined hands with the Taliban to protect their earlier prominence. When talking to Amir many years on Assef hysterically shares "He got mad and hit me harder, and the harder he kicked me, the harder I laughed. They threw me back in the cell laughing. I kept laughing and laughing ... He was on my side. He wanted me to live for a reason" (Hosseini, p. 154). The aforementioned panic-stricken articulations from The Kite Runner reflect how the act of being stripped of his power and dignity had engraved grave pains in Assef's heart. This is further restrengthened when he says with unjustifiable pride "Door to door we went, calling for the men and the boys. We'd shoot them right there in front of their families. Let them see . . I'd sweep the barrel of my machine gun around the room and fire and fire until the smoke blinded me" (p. 242). This is clearly one of the examples in The Kite Runner portraying the translation of emotional turmoil into destructive disposition.

Assef was apparently pushed out of his comfort zone and was bent on leaving no stones unturned in restoring it. But in the course of trying to do so, he did have to undergo bitter rape of his emotions and that reflected in his attitude, adding extra ounce of savagery to his personality as he constantly exploited Sohrab sexually. He emptied his store of his trauma of displacement on other more vulnerable Afghans, azaras, who he equally despised on ethnic and cultural grounds. A homosexual, Assef is a clear example of how one displaced has a tendency to ruthlessly manhandle the other displaced by all means. Assef here has perpetrated sexual misconduct on a minor, Sohrab, just the way he had raped Sohrab's father, Hassan, many years back. Suresh Lohani (2019) in "LGBTI in Nepal, Pakistan, and India: Law, religion, and individuals" presents a case that show how emotional displacement and physical displacement go together in many cases. He citing a case of LGBTI people in South Asia mentions how there are "the instances where some say that Pakistan is the gay-paradise while the others are forced into exile for being gay. In India, some are disowned by family for being homosexual and killing themselves" (p. 64-65). So, even Assef, on account of his sexual orientation might have subtly felt displaced from his community and that manifests in his unfeeling and extremist attitude towards others. Thus, for whatever reasons, one is compelled to leave their native setting, it will have a lasting impact on the psyche of those individuals.

Thus it would be an overstatement to posit that only upon being a victim of displacement that Assef acted the way he did for since his boyhood he embodied an image of notoriety of some kind as he strongly troubled Hassan who was culturally and economically inferior to him. Amir recalling Assef's younger days mentions "His well earned reputation for savagery preceded him on the streets" (Hosseini, p. 33). However, it would be no exaggeration to maintain that his notoriety gained extra mileage upon being displaced from his earlier power and pelf. It is thus quite a startling observation in the novel that the wrath of time acts in such a way that the displaced of yesterday and that of today may end up with a similar fate; yet the displaced of today retain some hangover of yesteryear dominance and continues to pain the displaced of yesterday. It is in this vein much more harrowing for the newly displaced to cope with the harshness of the changing scenario. This is because some exploitative agents of the past perpetuate the same heinous act thereby harnessing the adverse situation to their advantage. 
Geographical distantiation is yet another stark feature of displacement. The Kite Runner is rife with instances of geographical distantiation that have instigated because of displacement. Initially it is Ali settling into a territory quite hostile to peoples of his ethnic background followed by a second chapter of displacement in which he abandons his residence from the premises of Baba's mansion. Later, Baba and Amir were compelled into fleeing to America and the same was the story of the Afghan Army general who they met in the US. Likewise, even Sohrab was taken away from his hometown and mercilessly tortured. All the characters have been profoundly affected due to this detachment from their native settings.

To further paint the issue of displacement, the very title The Kite Runner can be taken into consideration. For example, itembodies the recklessness of life through the motif of a kite. The kite flying in the sky can be initially taken as reflection of a carefree life which Amir and, in a way Hassan, enjoy at the beginning of the novel. The kite flies freely in the sky but is still connected by thread to the spool, completely connected by a thin thread that is almost invisible. But once the kite is detached from the pool and is haphazardly flying in the sky, you cannot tell anything about its fate. Where it lands or how far it gets carried away by the wind or whether it is completely withered by harsh weather is hard to predict. What is certain, however, is it will lose its connectedness with the spool, its binding centre. In a similar vein, one can understand the plight of displacement. Just like a detached kite with displacement humans have to wander wherever the destiny takes them. This would mean a new phase of struggle, a new beginning in an alien land coupled with uncertainty of the future course. This is starkly evident both in the case of Hassan's family history and later in Amir's.

The pain of trauma can also be profusely found in Loo, a Nepali novel, by Nayan Raj Panday. The setting of the novel is a village in the Terai of Nepal that borders India. The novel has vibrantly perceptible characters such as Illaiya and others who are constantly harassed and humiliated by the Indian army personnel across the border. However, as the events begin to unfold the encroachment form the Indian side expedites and those people, formerly citizens of Nepal, eventually find themselves displaced "within their own land" although they have remained in the same location. The people have been robbed of their identity and are coerced into embracing a new identity. TutePandit, one of the characters in Loo, writes a painful letter to the writer in which he mentions "although our village is the same our address has been changed altogether without any information and news in the media" (Panday, p. 256). The newly tagged identity which TutePandit, Illaiya and other characters are forced to accept leaves them devoid of the identity with which they were born and raised. This case is analogous to that of the Russian soldiers harassing the fleeing Afghanis after the Russian soldiers stormed into Afghanistan and invaded it in the seventies. Although the manner in which the intimidation takes place in these two different works is quite dissimilar, the trauma that culminates as a result has a painful similarity.

One of the other burdens bestowed upon an individual or society by displacement is thus the resulting crisis of the status it brings along with it. On having to forsake the location of origin, one also has to constantly grapple with bygone cultural practices and mindsets in locations that are so unlike their native setting. Who, for example, is one in terms of personal stature and influence in a land that is poles apart different in terms of everything visible and non-visible? An example in this connection can be taken of the Afghani general and Baba who have to completely put behind all the eminence they enjoyed during the yesteryears in Afghanistan. On the one hand, Baba and general are quite evolving characters in a sense that they display a wonderful sense of adaptability as both of them learn the new ways of adjustment, and Americanize themselves in due course of time.

The price which the displaced pay for the "redemption", however, is too costly for many to afford. If one is to go through Narendra Dai by B.P. Koirala, it can be seen how Narendra Dai, the lead character, learns to embrace the ways of adjusting in a foreign setting of Benares when he reaches the venue with Munria, his ladylove beyond formal marriage, and starts up a new chapter of his life. Narendra was a man of immense influence in his village and always enjoyed an edge over others whenever he entered any discussion anywhere. In addition, he was also a character who translated his words into action. For example, once when he was asked to forget Munria, he declined and went ahead with her companionship and refused to resign to the family pressure. However, it was this very man who in Benares dumped all his egos and transformed into someone ready to accept change and move on. The case of Narendra's displacement was his love for Munria beyond the parameters of his 
marital life with Gauri. Narendra was not really in a position to nurture his love life amidst the prying and probing eyes of his family and society. Even with Munria, the story is no different. For the sake of her love she is more than willing to displace her old self and be replaced by a new one. Munria on stranding at Benares has to cater to the pleasure of men around as displacement has left her with little choice but to take up whatever it calls for she tolerates abusing phrases from people such as "where are you Munria ? Our stage is blank on your absence...come and entertain us" (Koirala, p. 51). She thus even converts into a pleasure object and eventually learns to internalize the changed identity and moves on.

What is even more intriguing about her is that on parting with Narendra she learns to befriend strangers and eventually enters into a relationship with a rich businessman, Jauharia, a gold smith, and woos him into marrying her. She then embarks on a journey of a new life from a completely different lane. This is one such example that demonstrates how displacement does not necessarily lead to everlasting impoverishment and that its ramifications may even lead to a new start and human empowerment at some level. Similar is the story of Pabitra in Amar Neupane's SetoDharti. Upon being displaced from her village due to her relationship with a saint, she explores different locations of India and shares with her friend "In which part of India did I not wander and what did I not do to support myself ?" (Neupane, p. 89). In the end, however, she transforms herself into an extremely successful character in terms of wealth and influence.

Similarly, displacement also helps characters grow more refined as the hardships of dislocation force people to mold them in such a way that they have little choice but to boldly face the situation and respond accordingly, be it through adaptation ,compromise or apt resistance. Thus characters avail the opportunity to transcend the comfort or discomfort of the cocoons and taste different "slices of life" which may profoundly help in enriching their lives. Displacement has to an extent even helped flatten the hierarchy between Afghans of different socio-economic class in the USA as Baba, General and the like stand as equals regardless of who they were back in Afghanistan.

Another instance of displacement can be analyzed at the psychological level with Amir perceiving himself as a victim and in this case the one responsible for his displacement is none other than Hassan himself. Amir always holds Hassan responsible for not being able to win over his father's heart. Hassan is the character better admired by Baba and this germinates the seeds of wrath and jealousy in Amir's heart for Hassan. The installment of his detest towards Hassan goes mounting with each passing day to such an extent that someone so "gentle" like Amir- for Hassan says "I'd sooner eat dirt" ( Hosseini, p. 47) than go against Amir's wishes- has to craftily resort to an act of treachery that would eventually succeed in pushing Hassan out of the household. The success of the trick, in fact a failed one as we readers can see, was heavily contingent upon Hassan's unflinching love and loyalty towards Amir as he simply refused to free himself of the charge slapped onto him by Amir. The accusation led to the painful exit of Ali and Hassan from the world of Amir but it would be wrong to conclude that Amir within himself wasn't internally displaced; he was always perceptibly or imperceptibly haunted that he was to blame for such a loathsome act. And the threads of this remorse scatter throughout the novel. Thus displacement operates on manifold levels and it may be difficult to say who feels the twinge of displacement most, the displaced one(s) or the one(s) to displace.

The other misery associated with displacement is the adverse psychic effect it injects in the minds of young children, helping them immunize even the most loathsome human affairs. In the novel, for example, Amir, the protagonist, takes for granted the love and care shown to him by Hassan. Although Amir can be excused on account of his age for sanctioning whatever kind of treatment he inflicted upon Amir, what is to blame more here is the normalization of the feeling that those who are displaced can be treated the way one likes. This feeling seems to have seeped into the mind of a young boy like Amir through characters such as Assef who was one of the Pashtuns like himself. Amir ends up ruining Hassan's life altogether. Amir is well aware of the pain he has caused to the duo as suggested by "That was when I understood the depth of the pain I had caused, the blackness of the grief I had brought onto everyone, that not even Ali's paralyzed face could mask his sorrow" (Hosseini 58). However, Amir has become so indifferent to Hassan's plight that even at the time of their departure he did not have any longing to urge him to stay back. He was devoid of any emotional attachment as gestured by his feeling "I stepped back and all I saw was rain through windowpanes 
that looked like melting silver" (p; 59).It is on the one hand an instance where a family is displaced or rather emotionally coerced into displacement.

However, on the other hand that Amir who initially takes for granted what he did to Hassan becomes the direct beneficiary of the situation as suggested in his monologue ".... I would have told, except that a part of me was glad. Glad that this would all be over with soon. Baba would dismiss them, there would be some pain, but life would move on" (Hosseini, p. 57). To look at it the other way, one can even argue that displacement, internal or external, of some characters often turns out to be a liberating experience for some in the society and as Robert Jay Lift on argues "In every society there is a group of 'designated victims' whom people create to 'life off' both economically and psychologically" ( qtd in KyeongHwangbo, p. 5). This can be apparently visualized in the novel as both Amir and Assef systematically exhibit their wrath and grievances upon Hassan in their own ways. There even appears no reason why one's sympathy should go with Amir and why Amir is any less detestable than Assef.

Critical race theory provides important tools for analyzing The Kite Runner. Ashok Bhusal in his article "The rhetoric of racism and anti-miscegenation laws in the United States" highlights the importance of using the tools of critical race theory and studying minorities and [bringing their stories, their voices, into academic scholarship" (p. 88). While feminism offers a framework for analyzing agonies and displacement of females in our society, critical race theory encourages us to study all minorities to examine the conditions of minorities and offer ways to improve their situations. As Bhusal (2017), in another article "Emphasizing the suppression of feminist voices," encourages us to look for minority people "who have been largely marginalized or ignored and reclaim their contributions in the twenty-first century" (p. 53). It means it is important that we bring stories of pains and sufferings of minority people in your society in an effort to combat discriminatory practices.

Suresh Lohaniin Scholar's Social Studies and Creative Arts talks about how culture forms our behaviors and our ways of life (p. 339). That said in the same book, he also mentions how traditional discriminatory practices that come with culture should be avoided. This novel has the characters that find themselves profoundly shaped by their culture, and that cultural capitals remains with the characters in some form even whey face most challenging ordeals of their lives. The mannerisms, optimism and confidence that Baba, for example, exudes show how our culture shapes our behavior. Khoseni also uses his positionality as an Afghan native to inject life into this novel. He is an "insider" in a sense that it is the socio-cultural and geographical scenario that he has been a part of that is vividly portrayed in the novel, and that in a way presents him as an emic researcher in this work that looks half a fiction and half an investigative piece. Suresh Lohani in "Constructing nontraditional Rhetoric: Critical study on Gloria Anzaldua and Suresh Canagarajah" states that "Emic approach in general can be understood as a research process of human beings that involves the words and experiences of the ones that participate in the research"(p.119). Although, Hosseni's work is not completely research based, it can still be argued that his fictionalized representation of the then Afghanistan is very close to the reality. It may for this reason that he has been able to create characters that truly mirror the conditions of Afghanistan during the troubled times.

\section{CONCLUSION}

To sum up, displacement has multitude of ramifications and of those few are positive glimmers such as empowerment and flattening of unjust hierarchy on grounds of class and race. Whether it is internal displacement -both within an individual entity or a concrete geographical boundary- or external one that expels the victims out of the nation frontiers, trauma is inalienably married to displacement. Sufferings and distantiation generally ensue displacement and migration kicks off. Be it the outcome of cultural divide or military invasion, displacement robs people of their identity, dignity and confidence. And interestingly, the burden of displacement is shared by both the displaced ones and the perpetrators of displacement, although it may appear as if it is always the displaced ones that have to come to terms with the lion's share of the trauma and misery. The Kite Runner has vividly portrayed this facet of displacement and exhibited how with displacement the external façade and the internal reality do not run parallel to each other. Rather they intersect at varying spatio-temporal locations.

\section{REFERENCES}

[1] Alexander, J. C. (2004).Toward a theory of cultural trauma." Ed. J.Alexander, et.al. Cultural Trauma and Collective Identity. ${ }^{\text {th }}$ ed. Berkley: University of California Press.1-30. 
[2] Bhusal, Ashok.(2017). The rhetoric of Racism and Anti-miscegenation laws in the United States. IAFOR Journal of Arts \& Humanities, 4(2), 83-89.https://doi.org/10.22492/ijah.4.2.07

[3] Bhusal, A. (2017). Emphasizing the suppression of feminist voices. International Journal of Humanities and Cultural Studies (IJHCS), 4(2), 53-57.

[4] Bhusal, A. (2019).The Rhetoric of Racism in Society. Journal of Research Innovation,9(1),111-114.

[5] Bhusal, A. et. al. (2018). Multilingual students in writing classes: A guide for teaching and learning. http://guidingmultilingualwriters.org/ Web. Accessed May 15, 2019.

[6] Hosseini, K. (2003). The Kite Runner. London: Bloomsbury Publishing.

[7] Hwangbo, K. (2005). Trauma, Narrative and the Marginal Self in Selected Contemporary American Novel. Diss. Graduate School of University of Florida, 2004. Florida: Florida University.

[8] Koirala, B.P. (2009).Narendra Dai. $8^{\text {th }}$ ed. Lalitpur: SajhaPrakasan.

[9] Kriesberg, L. (2003). Identity Issues. Ed. Guy Burgess and Heidi Burgess. Beyond Intractabiliy. $2^{\text {nd }}$ ed. Boulder: University of Colorado. 1-15.

[10] Lohani, S. (2016). LGBTI in NEPAL, Pakistan, and India: Law, religion, and individuals." MPhil Thesis, Department of English, Pokhara University.

[11] Lohani, S.(2019). "Constructing Nontraditional Rhetoric: Critical Study on Gloria Anzaldua and Suresh Canagarajah.”Journal of Research Innovation. 9(1).

[12] Lohani et al. (2015). Scholars' Social Studies and Creative Arts Series for Primary Level Students, approved by Curriculum Development CentrNepal, Kathmandu: Scholars Publications and Printing Pvt. Ltd.

[13] Neupane, A. SetoDharti. $1^{\text {st }}$ ed. Kathmandu: Fine Print, 2011. Print.

[14] Pandey, N. R. Luu. $1^{\text {st }}$ ed. Kathmandu: Shangrila Publication. 2066. Print.

Citation: Dinesh Lohani, Suresh Lohani. The Pain and Turmoil as Inevitable Result of Emotional and Physical Displacement in Hosseni's the Kite Runner. "International Journal on Studies in English Language and Literature (IJSELL), vol 7, no. 10, 2019, pp. 21-27. doi: http://dx.doi.org/10.20431/2347-3134.0710003.

Copyright: () 2019 Authors. This is an open-access article distributed under the terms of the Creative Commons Attribution License, which permits unrestricted use, distribution, and reproduction in any medium, provided the original author and source are credited. 